\title{
IMPLEMENTASI PERUBAHAN KEDUA KEBIJAKAN PENGAMPUNAN PAJAK TERKAIT PENGUNGKAPAN ASET SUKARELA DENGAN TARIF FINAL WAJIB PAJAK BADAN KPP MADYA JAKARTA BARAT
}

Selvi

Institut Ilmu Sosial dan Manajemen STIAMI

Selvi300990@gmail.com

ARTIKEL INFO

Keywords: Tax Amnesty, Tax Rate, Corporate

Taxpayers.

\section{ABSTRACT}

This study aims to analyze the implementation of the second amendment to tax amnesty policy related to disclosure of voluntary assets at the final rate of corporate taxpayers at West Jakarta Medium Tax Office. This study uses a qualitative descriptive approach. The results showed that the implementation of the second amendment to the tax amnesty policy related to the disclosure of voluntary assets with the final rate in West Jakarta Medium Tax Office according to six factors used by the authors, namely policy size and objectives, resources, communication between organizations, characteristics of implementing agents, dispositions (tendency) of the implementers, social, economic and political environments have been fulfilled.

But there are some things that need to be observed, namely the target of PASFinal policy is not appropriate for corporate taxpayers, which are due to corporate taxpayers more obedient, besides most of the corporate taxpayers have revealed their assets in tax amnesty policies, so the target should be more devoted to individual taxpayers. In addition, the participation of taxpayers to participate in this program is till lacking.

\section{PENDAHULUAN}

Rendahnya tingkat kesadaran Wajib Pajak dalam kepatuhan pembayaran pajak dan pelaporan pajaknya, membuat pemerintah terus berupaya menyusun strategi guna meningkatkan kepatuhan Wajib Pajak yang bertujuan untuk meningkatkan penerimaan negara. Salah satunya pada 1 Juli 2016 sampai dengan 31 Maret 2017 pemerintah mulai menerapkan kebijakan Pengampunan Pajak atau lebih dikenal dengan Tax Amnesty yang dituangkan dalam Undang-Undang Nomor 11 Tahun 2016.

Dengan adanya fasilitas kebijakan Pengampunan Pajak diperuntukkan bagi Wajib Pajak yang belum pernah mengungkapkan harta yang selama ini tidak dilaporkan dalam Surat Pemberitahuan Tahun (SPT) tanpa takut akan diperiksa kembali. Hal ini dikarenakan pengungkapan tersebut dilindungi Undang - Undang dan membuat adanya kepastian hukum dari sisi perpajakan melalui Surat Ketetapan Pengampunan Pajak.

Terbitnya Undang - Undang pengampunan pajak juga memiliki kaitan dengan kasus panama papers, maka dengan itu dengan diterapkannya Undang - Undang ini pemerintah berharap agar Wajib Pajak yang menyembunyikan hartanya di negara tax heaven countries dapat menarik kembali harta tersebut di Indonesia.

Tabel 1. Jumlah Wajib Pajak KPP Madya Jakarta Barat

\begin{tabular}{|l|c|}
\hline Uraian & Jumlah Peserta \\
\hline Jumlah Wajib Pajak & 1393 \\
\hline
\end{tabular}




\begin{tabular}{|l|c|}
\hline Jumlah Wajib Pajak Non Efektif & 1254 \\
\hline Jumlah Wajib Pajak Efektif & 833 \\
\hline $\begin{array}{l}\text { Jumlah Wajib Pajak Efektif Ikut } \\
\text { Pengampunan Pajak }\end{array}$ & 684 \\
\hline $\begin{array}{l}\text { Jumlah Wajib Pajak Efektif Tidak Ikut } \\
\text { Pengampunan Pajak }\end{array}$ & 149 \\
\hline
\end{tabular}

Terbukti dari data diatas masih belum optimalnya kebijakan pengampunan pajak, dengan masih adanya beberapa Wajib Pajak yang belum mengikuti kebijakan pengampunan pajak. Dari 833 Wajib Pajak aktif, 149 Wajib Pajak belum mengikuti kebijakan pengampunan pajak, sehingga dari sisi penerimaan pun pemerintah masih bisa dapat meningkatkan penerimaan negara dari Wajib Pajak yang belum mengikuti kebijakan pengampunan pajak.

Setelah berakhir masa pengampunan pajak, pemerintah mengeluarkan kebijakan Pengungkapan Asset Sukarela dengan Tarif Final atau lebih dikenal dengan PAS-Final yang dikeluarkan melalui Peraturan Menteri Keuangan (PMK) Nomor 165/PMK.03/2017 tentang perubahan kedua atas Peraturan Menteri Keuangan 118/PMK.03/2016 tentang pelaksanaan Undang-Undang Nomor 11 tahun 2016 tentang pengampunan pajak yang resmi berlaku per 17 November 2017 dan sudah mulai diundangkan pada 20 November 2017. Kebijakan ini diperuntukkan bagi Wajib Pajak yang sudah mengikuti ataupun belum mengikuti kebijakan pengampunan pajak dengan melaporkan harta yang belum diungkapkannya dalam Surat Pengungkapan Harta (SPH), ataupun pada SPT (Surat Pemberitahuan), selain itu kebijakan PASFinal ini memberikan fasilitas tidak dikenakannya sanksi pasal 18 UU pengampunan pajak sebesar 200\% bagi Wajib Pajak yang telah mengikuti kebijakan pengampunan pajak, dan $2 \%$ per bulan bagi Wajib Pajak yang tidak ikut kebijakan pengampunan pajak, namun dengan syarat belum diterbitkannya Surat Perintah Pemeriksaan (SP2).

Kebijakan PAS-Final ini sangat menyita perhatian publik, pasalnya pemerintah sudah menyampaikan kalau kebijakan pengampunan pajak hanya dilakukan sekali, guna mengoptimalkan penerimaan negara, serta meningkatkan kesadaran Wajib Pajak untuk membayar dan melaporkan pajaknya. Namun pada kenyataannya pemerintah justru memberikan kelonggaran kembali kepada Wajib Pajak dengan adanya kebijakan PAS-Final yang sebenarnya akan membuat Wajib Pajak tidak patuh dalam pembayaran dan pelaporan pajaknya, sehingga berfikir jika nantinya pemerintah akan mengadakan kebijakan sejenis pengampunan pajak lagi.

Akan tetapi, pemerintah menyakini melalui kebijakan PAS-Final ini diharapkan dapat menggenjot penerimaan pajak yang belum optimal serta memberi kelonggaran perpajakan untuk kondisi perekonomian yang belum pulih hingga saat ini. Dan juga dapat memberikan keadilan bagi para Wajib Pajak yang mungkin saja mengalami kesalahan pemasukan data ke SPT. Pasalnya, dalam aturan ini dijelaskan para Wajib Pajak bisa mengajukan keberatan jika ditemukan nilai asset yang sesuai oleh otoritas. Namun kemudahan perpajakan seperti ini tidak boleh terlalu sering diberikan kepada Wajib Pajak, supaya Wajib Pajak tidak terlena dengan kelonggaran yang selalu diberikan oleh pemerintah.

Dalam tulisan ini, penulis merumuskan dpertanyaan penelitian yakni bagaimana implementasi implementasi perubahan kedua kebijakan pengampunan pajak terkait pengungkapan asset sukarela dengan tarif final Wajib Pajak Badan di KPP Madya Jakarta Barat.

\section{KAJIAN LITERATUR}

Jurnal Pertama adalah penelitian yag dilakukan oleh Josephine A.A. Agbonika (2015) tentang "Tax Amnesty For Delinquent Tax Payers : A Cliche In Nigeria". Dari hasil penelitian tersebut dapat 
disimpulkan bahwa tantangan utama yang dihadapi oleh Federal Inland Revenue Service (FIRS) dan State Board of Internal Revenue (SBIR) adalah semakin meningkatkan tunggakan pajak. Banyaknya perusahaan yang telah bangkrut tanpa pernah membayar pajak sesuai waktu yang ditentukan. Maka dengan itu pemerintah menerapkan program Tax Amnesty yang dilakukan selama bertahun - tahun untuk mengatasi masalah penghindaran pajak untuk mendorong pembayaran pajak. Namun itu juga tetap dilakukan pemantauan bagi penghindar pajak yang memanfaatkan program Tax Amnesti sebagai bagian dari kebijakan reformasi di Nigeria supaya Wajib Pajak menjadi patuh.

Rujukan kedua adalah penelitian yang dilakukan oleh Waris Attiya, Abdul Latif Laila (2014) tentang "The Effect of Tax Amnesty on Anti - Money Laundering in Bangladesh". Dari hasil penelitian tersebut dapat disimpulkan bahwa maraknya aksi pencucian uang (money laundering) yang terjadi di Bangladesh, membuat pemerintah kesulitan untuk mengumpulkan dana dari sektor perpajakan. Maka dengan itu untuk meminimalkan aksi pencucian uang ini diadakanlah Program Tax Amnesty yang diberlakukan selama 12 sampai 13 tahun terakhir.

Jurnal Ketiga adalah penelitian yang dilakukan oleh Osman Fatih Saracoglu, Eren Caskurlu (2011) tentang "Tax Amnesty With Effects and Effecting Aspects : Tax Compliance, Tax Audits, and Enforcements Around ; The Turkish Case". Dari hasil penelitian tersebut dapat disimpulkan bahwa pemilihan Tax Amnesty secara berkala sebagai alat untuk meningkatkan kepatuhan pajak adalah tidak benar. Justru tax amnesty yang dilakukan secara berkala dapat menurunkan kepatuhan Wajib Pajak yang dikarenakan Wajib Pajak jujur yang melihat program Tax Amnesty dianggap sebagai penghargaan atas penghasut pajak. Oleh karena itu sangat sulit untuk memaksimalkan keberhasilan amnesty pajak melalui tindakan semacam itu. Di Turki Tax Amnesty juga merugikan prinsip keadilan. Beberapa model bersifat empiris menunjukkan bahwa kepatuhan pajak meningkat apabila didukung oleh pemeriksaan pajak. Pengulangan Tax Amnesty di Turki menyebabkan pembayar pajak tidak memenuhi kewajiban pajaknya.

Menurut Muttaqin (2013:30) Tax Amnesty atau Pengampunan Pajak adalah :"Merupakan pemberian fasilitas perpajakan berupa pembebasan dalam periode atau tenggang waktu tertentu dari pengenaan, pemeriksaan, pengusutan, dan penuntutanatas harta kekayaan atau penghasilan yang sebelumnya tidak atau belum sepenuhnya dikenakan pajak yang dilandasi oleh adanya pengakuan kesalahan dari Wajib Pajak dengan menyesali kesalahan tersebut dan janji tidak akan mengulangi kesalahan. Menurut William Beck (1990) dalam Osman (2011:95) berpendapat bahwa : One of previous studies examined that whether a voluntary settlement can be build regarding tax compliance by tax amnesty; on another one it is a concluded that tax compliance average decreases following tax amnesty, however this regression can be removed with a well planned tax amnesty and tax compliance builds up by increase in auditing and tax penalties after tax amnesty."

Menurut Darusalam (2015) tujuan pengampunan pajak atau tax amnesty:

1. Meningkatkan penerimaan pajak dalam jangka pendek.

Permasalahan penerimaan pajak yang cenderung menurun seringkali menjadi alasan pembenar diberikannya pengampunan pajak. Hal ini akan berdampak pada keinginan pemerintah untuk memberikan pengampunan pajak dengan harapan pajak yang dibayar oleh Wajib Pajak selama program pengampunan pajak akan meningkatkan penerimaan pajak.

2. Meningkatkan kepatuhan pajak dimasa yang akan datang. Kepatuhan Wajib Pajak merupakan salah satu penyebab pemberian pengampunan pajak. Para pendukung kebijakan pengampunan pajak umumnya berpendapat bahwa kepatuhan sukarela akan meningkat setelah program pengampunan pajak. Hal ini didasari pada harapan bahwa setelah program pengampunan pajak dilakukan, Wajib Pajak yang sebelumnya menjadi bagian dari sistem administrasi perpajakan, maka Wajib Pajak tersebut tidak akan bisa mengelak dan menghindar dari kewajiban perpajakannya.

3. Mendorong repatriasi modal atau asset.

Kejujuran dalam pelaporan sukarela atas data harta kekayaan setelah program tax amnesty merupakan salah satu tujuan pemberian pengampunan pajak. Dalm konteks pelaporan, data harta kekayaan tersebut, pemberian pengampunan pajak juga bertujuan untuk mengembalikan modal yang ada diluar negeri tanpa perlu membar pajak modal yang ada diluar negeri. Pemberian pengampunan 
pajak atas pengembalian modal yang ada diluar negeri dipandang perlu karena akan memudahkan otoritas pajak dalam meminta informasi tentang ada kekayaan Wajib Pajak kepada bank di dalam negeri.

4. Transisi ke sistem perpajakan yang baru

Pengampunan pajak dapat dijustifikasi ketika kebijakan pengampunan pajak digunakan sebagai alat transisi menuju sistem perpajakan yang baru.

Menurut Eric Le Borgne yang dikutip oleh Muttaqin (2013:31) bahwa: "Tax Amnesty disamping untuk meningkatkan pendapatan negara dalam jangka pendek, tax amnesty juga bertujuan untuk meningkatkan untuk meningkatkan kepatuhan Wajib Pajak sehingga dapat meningkatkan keadilan horizontal dan meningkatkan pendapatan dalam jangka menengah."

Menurut Suharno (2016:5), asas pengampunan pajak ada empat, yaitu :

1. Asas kepastian hukum, adalah pelaksanaan pengampunan pajak harus dapat mewujudkan ketertiban dalam masyarakat melalui jaminan kepastian hukum.

2. Asas keadilan, adalah pelaksanaan pengampunan pajak menjunjung tinggi keseimbangan hak dan kewajiban dari setiap pihak yang terlibat.

3. Asas kemanfaatan, adalah seluruh pengaturan kebijakan pengampunan pajak bermanfaat bagi kepentingan negara, khususnya dalam memajukan kesejahteran umum.

4. Asas kepentingan nasional, adalah pelaksanaan pengampunan pajak mengutamakan kepentingan bangsa, negara, dan masyarakat diatas kepentingan lainnya.

\section{METODE PENELITIAN}

Penelitian ini merupakan penelitian kualitatif. Adapun Teknik pengumpulan data dengan cara observasi di KPP Madya Jakarta Barat, wawancara dengan beberapa informan yakni Ibu Mukti Wardhani selaku Account Representative KPP Madya Jakarta Barat, Farid Ma'ruf selaku Account Representative KPP Madya Jakarta Barat, Bapak Reinaldy Saputra (Accounting CV Makmur) selaku Wajib Pajak KPP Madya Jakarta Barat, Ibu Vira (Staff Pajak PT Kompas Radio Semarang) selaku Wajib Pajak KPP Madya Jakarta Barat serta Ibu Murni selaku Konsultan Pajak. Selain itu, penulis jg menggunakan data sekunder dari KPP Madya Jakarta Barat. Pengumpulan data yang dilakukan penulis kemudian dilakukan analisis dengan metode triangulasi.

\section{HASIL PENELITIAN DAN PEMBAHASAN}

\section{Implementasi Perubahan Kedua Kebijakan Pengampunan Pajak Terkait Pengungkapan Asset Sukarela dengan Tarif Final Wajib Pajak Badan Pada KPP Madya Jakarta Barat.}

Sebagai perwujudan suatu tindakan untuk memecahkan suatu masalah yang tejadi di masyarakat pemerintah menerapkan suatu kebijakan publik. Salah satu kebijakan tersebut adalah perubahan kedua kebijakan pengampunan pajak terkait pengungkapan asset sukarela dengan tarif final atau biasa disebut dengan kebijakan PAS-Final yang berlaku pada November 2017 lalu. Sebelum diterapkannya kebijakan tersebut, suatu kebijakan publik dibutuhkan tahap-tahap dalam pembuatannya dimulai dari tahap penyusunan agenda, tahap formulasi kebijakan, tahap adopsi kebijakan, tahap implementasi kebijakan, dan yang terakhir tahap evaluasi kebijakan. Setelah kebijakan tersebut diterapkan maka tahap kebijakan PAS-Final ini telah memasuki tahap implementasi kebijakan. Guna mencapai keberhasilan implementasi perubahan kedua kebijakan pengampunan pajak terkait pengungkapan asset sukarela dengan tarif final ini terdapat 6 faktor yang mempengaruhi menurut Van Meter Van Horn, dalam Winarno (2002:102) yaitu Standar Ukuran dan Tujuan kebijakan, Sumber Daya, Karakteristik Agen Pelaksana, Sikap (Disposisi) Para Pelaksana, Komunikasi Antar Organisasi terkait Pelaksanaan, dan Lingkungan sosial ekonomi dan politik. 
Faktor-faktor tersebut kaitannya dengan Implementasi Perubahan Kedua Kebijakan Pengampunan Pajak Terkait Pengungkapan Asset Sukarela dengan Tarif Final Wajib Pajak Badan Pada KPP Madya Jakarta Barat adalah sebagai berikut :

\section{a. Ukuran dan Tujuan Kebijakan}

Ukuran dan tujuan kebijakan sanagat menentukan keberhasilan pencapaian tujuan dari implementasi perubahan kedua kebijakan pengampunan pajak terkait pengungkapan asset sukarela dengan tarif final. Pemahaman tentang maksud umum dari suatu standar dan tujuan kebijakan adalah penting. Implementasi kebijakan akan berhasil, atau juga bisa jadi gagal apabila para pelaksana tidak sepenuhnya menyadari standar dan tujuan kebijakan. Ketetapan tujuan dan sasaran kebijakan dapat terbangun dengan adanya keterkaitan para pelaksana supaya tercapainya keberhasilan suatu kebijakan, yang dalam hal ini adalah perubahan kedua kebijakan pengampunan pajak terkait pengungkapan asset sukarela dengan tarif final.

Berdasarkan wawancara degan Ibu Mukti Wardhani selaku Account Representatif pada KPP Madya Jakarta Barat, beliau mengatakan bahwa tujuan diadakannya kebijakan adalah memberikan kesempatan bagi wajib pajak yang belum mengikuti ataupun yang telah mengikuti Tax Amnesty namun belum mengungkapkan sendiri semua hartanya, namun dengan syarat belum diterbitkannya surat perintah pemeriksaan.

Kemudian dari hasil wawancara dengan Bapak Farid Ma'ruf selaku Account Representatif pada KPP Madya Jakarta Barat, beliau mengatakan tujuan dari diadakannya kebijakan ini adalah memberikan kesempatan bagi wajib pajak yang telah mengikuti Tax Amnesty dan juga yang belum mengikuti Tax Amnesty namun masih terdapat harta yang belum terlaporkan untuk mengungkapkan hartanya supaya terhindar dari sanksi-sanksi.

Dalam hal ini tujuan yang disampaikan kedua implementor sama, yaitu sama-sama memberikan kesempatan bagi wajib pajak yang masih mempunyai harta yang belum diungkapkan agar segera diungkapkan melalui kebijakan PAS-Final ini guna tercapainya kebijakan ini dan juga peningkatan pendapatan negara.

Karena kebijakan ini sendiri baru berlaku belum sampai setahun maka pencapaiannya sendiri belum terlalu jelas, pada KPP Madya Jakarta Barat sendiri baru 2 wajib pajak yang mengikuti kebijakan ini, yang dikarenakan tidak adanya jangka waktu yang diberikan oleh pemerintah terkait kebijakan ini, wajib pajak dapat melakukan pengungkapan asset secara sukarela kapanpun dengan syarat belum diadanya surat perintah pemeriksaan.

\section{b. Sumber Daya}

Ketersediaan sumber daya dalam melaksanakan sebuah kebijakan merupakan salah satu faktor yang harus diperhatikan. Dalam hal ini sumber daya yang dimaksud adalah sumber daya manusia, sumber daya finansial, dan sumber daya fasilitas. Indikator sumber daya terdiri dari beberapa elemen, yaitu :

\section{Sumber Daya Manusia}

Keberadaan sumber daya manusia dalam implementasi kebijakan memiliki hal yang penting. Sumber daya manusia merupakan sumber daya utama untuk dapat melaksanakan sebuah kebijakan. Sumber daya yang memadai dan kompeten dibidangnya sangat dibutuhkan untuk dapat mengimplementasikan kebijakan yang baik. Adanya sumber daya lain seperti finansial dan prasarana tidak akan menjamin keberhasilan implementasi apabila tidak didukung dengan sumber daya manusia yang memadai.

Berkenaan dengan sumber daya manusia, petugas yang ditetapkan telah melewati uji standar yang ditetapkan terlebih dahulu, mereka mempunyai pengalaman dan keahlian dibidang tersebut, sehingga kecil kemungkinan yang ada untuk memberikan informasi yang keliru ataupun melakukan kesalahan dalam penyampaian informasi kepada wajib pajak, karena sebelum diadakan sosialisasi (penyampaian) kepada wajib pajak, SDM di KPP Madya Jakarta Barat ini diberikan 
training terlebih dahulu terkait kebijakan yang akan di informasikan, pernyataan hasil wawancara dengan Ibu Mukti Wardhani dan Bapak Farid Ma'rud selaku Account Representative KPP Madya Jakarta Barat.

\section{Sumber Daya Finansial}

Sumber daya finansial menjadi penting jika didalam pelaksanaan kebijakan membutuhkan budget atau dana yang diperlukan. Aspek finansial disini lebih ke sosialisasi kebijakan tersebut. Berdasarkan hasil wawancara dengan Ibu Mukti Wardhani selaku Account Representatif KPP Madya Jakarta Barat sumber dana finansial (anggaran) disini dikhususkan untuk dana-dana dalam sosialisasi, karena apabila ada kebijakan terbaru KPP Madya Jakarta Barat akan segera menyediakan waktu dan tempat untuk mengadakan sosialisasi tersebut.

3. Sumber Daya Sarana dan Prasarana

Sarana dan Prasarana yang dimaksudkan adalah sarana dan prasarana yang digunakan untuk operasional implementasi kebijakan yang meliputi : gedung, tanah, dan sarana yang akan mempermudah dan memberikan pelayanan dalam melaksanakan kebijakan tersebut. Ibu Mukti Wardhani dan Bapak Farid Ma'ruf berpendapat bahwa tidak ada penambahan fasilitas yang dikhususkan untuk kebijakan PAS-Final ini, fasilitas yang diberikan untuk wajib pajak yang mengikuti kebijakan PAS-Final sama dengan wajib pajak yang akan lapor pajak biasa, karena fasilitas yang ada sendiri dirasa sudah cukup dalam menunjang kebijakan tersebut, namun apabila ada wajib pajak yang ingin menanyakan kebijakan tersebut lebih lanjut maka dapat menghubungi Account Representatif masing-masing via telepon.

Wajib pajak KPP Madya Jakarta Barat juga mengakui fasilitas yang diberikan oleh KPP Madya Jakarta Barat sudah sangat cukup dalam mengikuti kebijakan PAS-Final ini ataupun kebijakan-kebijakan lainnya.

Berikut adalah beberapa foto fasilitas sarana dan prasarana yang ada di KPP Madya Jakarta Barat.

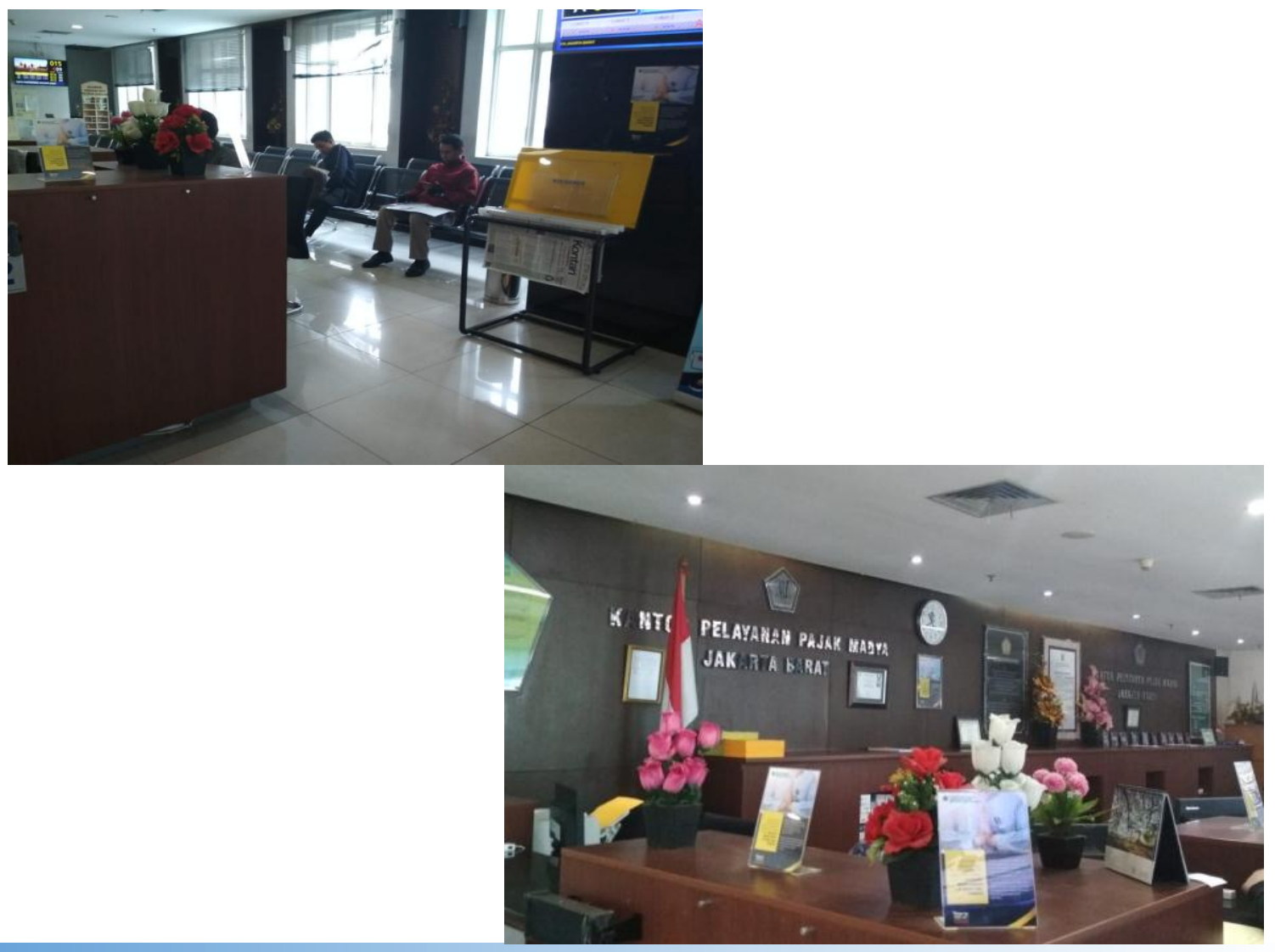




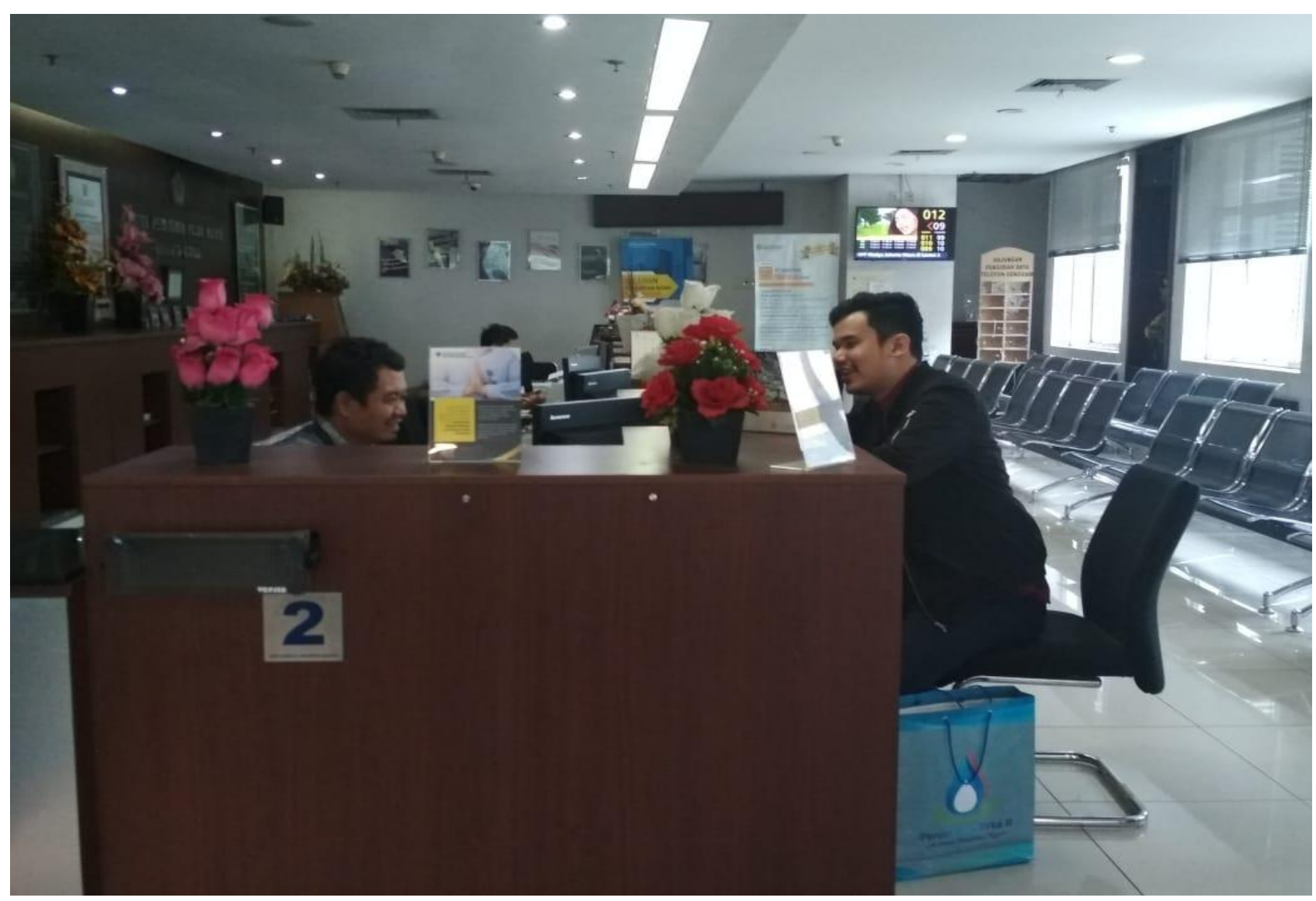

Gambar 1. Fasilitas Sarana dan Prasarana di KPP Madya Jakarta Barat

\section{c. Komunikasi Antar Organisasi}

Dalam banyak program implementasi kebijakan, sebagai realitas dari program kebijakan perlu hubungan yang baik antar instansi terkait, yaitu dukungan komunikasi dan koordinasi. Untuk itu, diperlukan koordinasi dan kerjasama antar instansi bagi keberhasilan suatu program tersebut. Komunikasi dan koordinasi merupakan salah satu hal terpenting dari sebuah organisasi agar programprogramnya tersebut dapat direalisasikan dengan tujuan serta sasarannya.

Berdasarkan hasil wawancara menurut peneliti mengenai komunikasi antar agen pelaksana sudah cukup baik karena sudah ada SOP yang mengatur mengenai tugas dari masing-masing pelaksana tersebut. Namun untuk komunikasi kepada masyarakat umum belum sesuai dengan harapan, karena masih kurangnya sosialisasi dari KPP Madya Jakarta Barat mengenai perubahan kedua kebijakan pengampunan pajak terkait pengungkapan asset sukarela dengan tarif final ini.

\section{d. Karakter Agen Pelaksana}

Dalam pengimplementasian suatu kebijakan, karakter dari para pelaksana kebijakan atau program harus berkarakteristik keras dan ketat pada aturan serta taat pada sanksi hukum yang belaku. Kinerja implementasi tanggung jawab sosial melalui pengembangan masyarakat dan sangat banyak dipengaruhi oleh ciri-ciri yang tepat serta cocok dengan para agen pelaksananya. Untuk mendukung kebijakan PAS-Final tersebut, pelaksana yang terlibat adalah sebagai berikut :

1. Account Representatif

a. Waskon 1 bertugas menangani pengajuan permohonan wajib pajak meliputi pemindahbukuan, SPMKP, dll. 
b. Waskon 2-Waskon 4(Galpot) bertugas memantau kepatuhan, pelaporan serta pembayaran dan penggalian potensi wajib pajak.

2. Seksi Pelayanan bertugas menerima berkas SPT dan permohonan wajib pajak, administrasi berkas wajib pajak, dan pencetakan produk hukum.

3. PDI (Pengolahan Data dan Informasi) bertugas mengelola IT (jaringan) kantor, koordinator aplikasi milik DJP, dan administrasi data wajib pajak dan penerimaan.

Dari ketiga pelaksana yang terlibat tersebut saling berkaitan untuk keberhasilan pelaksanaan perubahan kedua kebijakan pengampunan pajak terkait pengungkapan asset sukarela dengan tarif final wajib pajak badan pada KPP Madya Jakarta Barat.

\section{e. Kecenderungan (Disposisi) Agen Pelaksana}

Salah satu faktor yang mempengaruhi efektivitas implementasi kebijakan adalah sikap implementor. Jika implementor setuju dengan bagian-bagian isi dari kebijakan maka mereka akan melaksanakan dengan senang hati, tetapi apabila pandangan mereka berbeda dengan pembuat kebijakan maka proses implementasi akan mengalami banyak masalah dalam disposisi. Disposisi atau sikap pelaksana akan menimbulkan hambatan-hambatan yang nyata dalam pelaksanaan implementasi kebijakan tersebut.

Berdasarkan hasil wawancara dengan wajib pajak, wajib pajak setuju dengan diadakannya kebijakan ini, namun kebijakan ini kurang tepat untuk wajib pajak badan karena sebagian besar wajib pajak badan telah mengungkapkan semua hartanya pada saat Tax Amnesty, dan sasaran kebijakan ini lebih ditepatkan untuk wajib pajak orang pribadi.

Hasil wawancara berikutnya dengan pihak akademisi di bidang perpajakan juga ikut serta mendukung adanya kebijakan ini karena dianggap cara yang tepat untuk menjaring wajib pajak yang belum mengungkapkan hartanya setelah berakhirnya masa Tax Amnesty, serta dapat meningkatkan pendapatan negara dari hasil pengungkapan harta wajib pajak tersebut, namun ada dampak negatif pula bagi kebijakan ini karena dapat menurunkan kepatuhan wajib pajak karena dianggap tidak adanya konsistensi yang dilakukan pemerintah dalam mengeluarkan suatu kebijakan yang dikarenakan pada awal dikeluarkannya kebijakan Tax Amnesty pemerintah mengeluarkan statement jika tidak akan mengeluarkan kebijakan seperti Tax Amnesty, tetapi pada kenyataannya pemerintah kembali mengeluarkan kebijakan serupa walaupun berbeda cukup signifikan dari segi tarifnya, namun tetap saja kebijakan ini dianggap sama.

Indikator kedua dalam faktor disposisi adalah pemahaman terhadap kebijakan. Pemahaman penting dimiliki oleh implementor karena tanpa disadari pemahaman yang memadai dari pelaksana kebijakan, maka tidak mungkin implementor dapat melaksanakan sesuai tujuannya. Hasil wawancara oleh Ibu Mukti Wardhani dan Bapak Farid Ma'ruf selaku Account Representative KPP Madya Jakarta Barat menyatakan pengetahuan dan pemahaman petugas pajak mengenai kebijakan PAS-Final ini sudah sangat baik, karena saat diterbitkannya kebijakan terbaru, maka petugas pajak diberikan training terlebih dahulu agar petugas pajak memahami kebijakan PAS-Final, materi kebijakan sendiri diberikan dari Kanwil DJP sehingga petugas pajak yang ada di KPP Madya Jakarta Barat sangat memahami kebijakan PAS-Final ini.

\section{f. Lingkungan Sosial, Ekonomi, dan Politik}

Variabel ini mencakup sumber daya ekonomi lingkungan yang dapat mendukung keberhasilan implementasi kebijakan, sejauh mana kelompok-kelompok kepentingan memberikan dukungan bagi implementasi kebijakan; karakteristik para partisipan, yakni mendukung atau menolak; bagaimana opini publik yang ada di lingkungan dan apakah elite politik mendukung implementasi kebijakan.

Berdasarkan hasil wawancara peneliti dapat menyimpulkan bahwa mengenai kondisi lingkungan sosial, ekonomi, dan politik terhadap perubahan kedua kebijakan pengampunan pajak terkait pengungkapan asset sukarela dengan tarif final wajib pajak badan yakni untuk kondisi sosial sendiri tidak terlalu berpengaruh karena untuk wajib pajak badan telah memiliki orang yang dianggap mampu 
dalam memahami kebijakan PAS-Final ini, sedangkan untuk kondisi ekonomi berpengaruh dalam kebijakan ini karena kesanggupan dari wajib pajak dalam membayar uang tebusan sangat berpengaruh dalam perekonomian wajib pajak. Dan untuk kondisi politik pastinya berpengaruh karena diadakannya kebijakan sendiri apalagi kebijakan yang dikeluarkan dari Peraturan Menteri Keuangan (PMK) pastinya tidak lepas dari elite politik yang terlibat didalamnya.

Tabel 2 . Matriks Hasil Peneltian

\begin{tabular}{|c|c|c|c|}
\hline Faktor & $\begin{array}{c}\text { Keterangan } \\
\text { Faktor }\end{array}$ & Indikator & $\begin{array}{l}\text { Keterangan } \\
\text { Indikator }\end{array}$ \\
\hline $\begin{array}{l}\text { 1. Ukuran dan } \\
\text { tujuan } \\
\text { kebijakan }\end{array}$ & $\sqrt{ }$ & $\begin{array}{llll}\text { a. } & \begin{array}{l}\text { Standar } \\
\text { jelas }\end{array} & \text { kebijakan } & \text { yang } \\
\text { b. } & \begin{array}{l}\text { Sasaran } \\
\text { jelas }\end{array} & \text { kebijakan } & \text { yang } \\
& & \end{array}$ & $\begin{array}{l}\sqrt{ } \\
X\end{array}$ \\
\hline 2. Sumber Daya & $\sqrt{ }$ & $\begin{array}{ll}\text { a. } & \text { Sumber Daya Manusia } \\
\text { b. } & \text { Sumber Daya Finansial } \\
\text { c. } & \text { Sumber Daya metoda }\end{array}$ & $\begin{array}{l}\sqrt{ } \\
\sqrt{ } \\
\sqrt{ }\end{array}$ \\
\hline $\begin{array}{l}\text { 3. Komunikasi } \\
\text { Antar } \\
\text { Organisasi }\end{array}$ & $\sqrt{ }$ & $\begin{array}{l}\text { a. Komunikasi antar pihak } \\
\text { terkait } \\
\text { b. Koordinasi antar organisasi }\end{array}$ & $\begin{array}{l}\sqrt{ } \\
\sqrt{ }\end{array}$ \\
\hline $\begin{array}{ll}\text { 4. } & \text { Karakteristik } \\
\text { Agen Pelaksana }\end{array}$ & $\sqrt{ }$ & $\begin{array}{l}\text { a. Struktur Birokrasi } \\
\text { b. Norma-norma dalam } \\
\text { organisasi } \\
\text { c. Pola-pola hubungan dalam } \\
\text { organisasi }\end{array}$ & $\begin{array}{l}\sqrt{ } \\
\sqrt{ } \\
\sqrt{ }\end{array}$ \\
\hline $\begin{array}{l}\text { 5.Disposisi } \\
\text { Implementor }\end{array}$ & $\sqrt{ }$ & $\begin{array}{ll}\text { a. } & \text { Respon Implementor } \\
\text { Terhadap Kebijakan } \\
\text { b. Pemahaman } \\
\text { Kebijakan Terhadap } \\
\text { c. Preferensi nilai yang } \\
\text { dimiliki }\end{array}$ & $\begin{array}{l}\sqrt{ } \\
\sqrt{ }\end{array}$ \\
\hline $\begin{array}{lr}\text { 6.Kondisi } & \text { Sosial, } \\
\text { Ekonomi, } & \text { dan } \\
\text { Politik } & \end{array}$ & $\sqrt{ }$ & $\begin{array}{llr}\text { a. } & \begin{array}{l}\text { Sumberdaya } \\
\text { Lingkungan }\end{array} \\
\text { b. } & \text { Karakteristik } \\
& \text { Partisipan } & \text { Para } \\
\end{array}$ & $\sqrt{ }$ \\
\hline
\end{tabular}


Dalam pelaksanaan suatu kebijakan tentunya akan selalu ada hambatan yang dihadapi dari pihakpihak terkait. Hambatan yang dihadapi dalam implementasi perubahan kedua kebijakan pengampunan pajak terkait pengungkapan asset sukarela dengan tarif final wajib pajak badan di KPP Madya Jakarta Barat, yaknik pihak KPP Madya Jakarta Barat selaku implementor dan wajib pajak. Kebijakan PAS-Final merupakan kebijakan terbaru yang baru diundangkan pada November 2017, maka belum dapat berjalan secara optimal. Hal itu disebabkan karena adanya kendala-kendala yang dihadapi oleh KPP Madya Jakarta Barat. Kendala-kendala yang dihadapi tersebut terbagi menjadi dua bagian yakni kendala internal dan eksternal.

\section{a. Kendala Internal}

Kendala internal merupakan masalah yang dihadapi oleh pihak internal selaku implementor atau pelaksana kebijakan. Kendala yang dihadapi yakni mengenai sosialisasi. Berdasarkan wawancara dengan Ibu Mukti Wardhani, beliau mengatakan kurangnya sosialisasi yang dilakukan KPP Madya Jakarta Barat mengenai kebijakan PAS-Final ini, yang dikarenakan sosialisasi serta promosi sudah dilakukan secara besar-besaran pada saat kebijakan Tax Amnesty, bahkan promosi Tax Amnesty mengundang wajib pajak melakukan forum dengan Menteri Keuangan dan juga Dirjen Pajak, sehingga mereka yakin sebagian besar wajib pajak KPP Madya Jakarta Barat telah mengungkapkan semua hartanya pada saat Tax Amnesty.

b. Kendala Eksternal

Kendala eksternal merupakan masalah yang dihadapi pihak eksternal dalam menghadapi perubahan kedua kebijakan pengampunan pajak terkait pengungkapan asset sukarela dengan tarif final wajib pajak badan. Yakni dukungan dan partisipasi wajib pajak. Hal ini disebabkan karena kurangnya sosialisasi yang dilakukan oleh KPP Madya Jakarta terkait kebijakan PAS-Final ini, serta terlalu berdekatannya kebijakan PAS-Final dengan berakhirnya masa Tax Amnesty. Sudah banyak wajib pajak yang mengikuti kebijakan Tax Amnesty, sehingga partisipasi wajib pajak mengenai kebijakan PAS-Final ini sangat kurang, terutama untuk wajib pajak badan.

\section{KESIMPULAN}

Setelah melakukan penelitian didapati bahwa implementasi program cukup baik berdasarkan factorfaktor yang dikemukakan Van Meter Van Horn. Namun ada beberapa hal yang perlu dicermati yakni sasaran dari kebijakan PAS-Final ini belum tepat untuk wajib pajak badan, yang dikarenakan wajib pajak badan lebih patuh, selain juga sebagian besar dari wajib pajak badan sudah mengungkapkan hartanya pada kebijakan pengampunan pajak, sehingga sasarannya seharusnya lebih dikhususkan kepada wajib pajak orang pribadi. Selain itu, pertisipasi Wajib Pajak untuk mengikuti program ini masih kurang.

\section{DAFTAR PUSTAKA}

Agbonika.AA Josephine. 2015. Tax Amnesty for Delinquent Tax Payers: A Cliché in Nigeria. Global Journal of Politics and Law Research Vol. 3 No.3 pp 105-120, June 2015. UK: European Centre for Research Training and Development UK

Attiya, Waris \& Abdul Latif Laila. 2014. The Effect of Tax Amnesty on Anti-Money Laundering in Bangladesh. Journal of Money Laundering Control. 17. 243-255. 10.1108/JMLC-04-2013-0011.

Muttaqin, Zainal. 2013. Tax Amnesty di Indonesia. Bandung: PT. Refika Aditama.

Saracoglu, Osman Fatih \& Eren Caskurlu. 2011. Tax Amnesty with Effects and Effecting Aspects: Tax Compliace, Tax Audits and Enforcement Around: The Turkish Case. International Journal of Business and Social Science Vol 2 No 7 - Special Issue-April 2011

Suharno. 2016. Panduan Amnesti Pajak Indonesia. Jakarta: Kompas. 
Winarno, Budi. 2002. Kebijakan Publik : Teori dan Proses. Yogyakarta: Media Pressindo.

\section{Peraturan Perundang-Undangan}

Peraturan Menteri Keuangan (PMK) Nomor 165/PMK.03/2017 tentang perubahan kedua atas Peraturan Menteri Keuangan (PMK) Nomor 118/PMK.03/2016 tentang pelaksanaan Undang-Undang Nomor 11 tahun 2016 tentang pengampunan pajak.

\section{Sumber Lain}

Darussalam. 2015. Inside Tax Manfaatkan Pengampunan Pajak: Pahami dan Manfaatkan Reiventing Policy Edisi 31. Jakarta: PT. Dimensi Internaional Tax. 